\title{
Trees and springs as social property: a perspective on degrowth and redistributive democracy from a Brazilian squatter community
}

\author{
Jonathan DeVore ${ }^{1}$ \\ University of Bonn, Germany
}

\begin{abstract}
Questions concerning the maldistribution of property and productive resources continue to inform debates about how to bring about societies that are livable, equitable, and ecologically sustainable. In the diverse imaginaries of revolutionary, utopian, socialist, and anti-capitalist politics - together with their adversariesthe notions of "collective" and "private" property have often been conceived as mutually exclusive and exhaustive alternatives. Drawing from several years of ethnographic research with rural squatters in the cacao lands of Bahia, Brazil, the author brings together alternative ways of conceptualizing property that can help overcome this lingering dichotomy and fruitfully inform new political projects. The article examines local practices of property-making through two cases focused on the private ownership and stewardship of natural springs, and the processes whereby squatters convert forest into agroforest. The analysis highlights the ways in which these "private" properties are intersected by "public" interests and "collective" practices, while considering the different kinds of relations that these intersections afford among people and between humans and the non-human environment. Based on these cases, the author suggests that current conversations about "degrowth" may benefit by drawing together frameworks from political ecology, economic anthropology, and property jurisprudence. The presentation concludes by highlighting potential synergies between concerns for degrowth and claims for property democratization.
\end{abstract}

Key Words: degrowth; redistributive democracy; squatters; agroforests; water resources; property rights; private property; commoning; cacao zone; Atlantic Forest; Brazil

\section{Résumé}

Les questions relatives à la mauvaise distribution de la propriété et des ressources productives continuent à informer les débats sur les façons d'établir des sociétés qui soient vivables, équitables et écologiquement durables. Dans les divers imaginaires des politiques révolutionnaires, utopiques, socialistes, et anticapitalistes_ainsi que chez leurs adversaires-les notions de propriété «collective» et «privée» ont souvent été conçues comme des alternatives mutuellement exclusives et exhaustives. Se fondant sur plusieurs années de recherche ethnographique avec des squatters ruraux dans les terres à cacao de Bahia, au Brésil, l'auteur passe en revue d'autres façons de conceptualiser la propriété susceptibles d'aider à surmonter cette dichotomie persistante et à informer de nouveaux projets politiques. L'article examine les pratiques locales de formation de la propriété à travers deux cas centrés sur la gestion et la propriété privées de sources d'eau naturelles, et les processus à travers desquels les squatters transforment la forêt en agroforêt. L'analyse met en évidence les façons dont ces propriétés «privées» sont traversées par des intérêts «publics» et des pratiques «collectives», tout en prenant en compte les différents types de relations que ces intersections permettent entre les personnes, et aussi entre les humains et l'environnement non humain. Sur la base de ces

\footnotetext{
${ }^{1}$ Dr. Jonathan DeVore, Lecturer, Department for the Anthropology of the Americas, University of Bonn, Germany. Email: jonathan.devore "at" yale.edu. I thank Susan Paulson, Lisa Gezon, and Casey Walsh for critical comments and helpful suggestions on earlier versions of this article and Alba Díaz Geada and Daniel Tubb for long conversations about a number of the issues presented here. Michael A. Vincent and Kevin M. Flesher offered assistance with botanical and ecological questions, respectively. William DeVore, as always, offered comments on different versions of the article and helped proof the manuscript. This article was completed with generous post-doctoral support from the Program in Agrarian Studies at Yale University. Fieldwork was funded by: NSF Doctoral Dissertation Improvement Grants (2009); Fulbright-Hays, Doctoral Dissertation Research Abroad (2009); American Philosophical Society, Lewis and Clark Fund (2010); Rackham Graduate School, University of Michigan, International Research Award (2010); and Fulbright Institute of International Education (2003-2004). This is the fourteenth article in Lisa L. Gezon and Susan Paulson (eds.) 2017. "Degrowth, culture and power", Special Section of the Journal of Political Ecology, 24: 425-665.
} 
cas, l'auteur suggère que les débats en cours sur la «décroissance» pourraient tirer profit d'une mise en commun des cadres conceptuels de l'écologie politique, de l'anthropologie économique, et de la jurisprudence sur la propriété. La présentation conclut en mettant en évidence les synergies potentielles entre les préoccupations en faveur de la décroissance et les demandes de démocratisation de la propriété.

Mots-clés: décroissance; la démocratie redistributive; squatters; agroforêts; ressources en eau; droits de propriété; propriété privée; commoning; zone du cacao; Forêt Atlantique; Brésil

\section{Resumen}

Los debates sobre cómo formar sociedades más llevaderas, equitativas y ecológicamente sustentables se siguen nutriendo de interrogantes acerca de la mala distribución de la propiedad y los recursos de producción. En los diversos imaginarios de las ideas políticas revolucionarias, utopistas, socialistas y anticapitalistasjunto con sus adversarios_comúnmente se ha concebido a las nociones de propiedad "colectiva" y "privada" como alternativas mutuamente excluyentes y exhaustivas. Derivadas de varios años de investigación etnográfica con ocupantes (squatters) rurales en las tierras del cacao en Bahía, Brasil, el autor presenta, de manera conjunta, distintas maneras alternativas de conceptualizar la propiedad que pueden superar esta persistente dicotomía y nutrir nuevos proyectos políticos de manera provechosa. El artículo estudia prácticas locales de creación de la propiedad a través de dos casos enfocados en la posesión y gestión privada de los manantiales naturales y los procesos mediante los cuales los ocupantes de tierra convierten al bosque en agrobosque. El análisis hace énfasis en las maneras en las que estas propiedades "privadas" se intersectan con intereses "públicos" y prácticas "colectivas," a la par que se consideran los distintos tipos de relaciones que éstas intersecciones permiten entre las personas, así como entre los humanos y el medio ambiente no humano. Basado en estos casos, el autor sugiere que las conversaciones actuales sobre "decrecimiento" podrían beneficiarse del uso conjunto de los marcos teóricos de la ecología política, la antropología económica y la jurisprudencia. La presentación concluye resaltando potenciales sinergias entre las preocupaciones por el decrecimiento y las demandas de democratización de la propiedad.

Palabras clave: decrecimiento; democracia redistributiva; ocupantes de tierra; agrobosques; recursos hídricos; derechos de propiedad; propiedad privada; commoning; zona del cacao; Mata Atlántica; Brasil

\section{Degrowth and redistributive politics}

The question of "degrowth" has been raised in recent years, particularly in Western European countries, in response to the existential threat portended by unbridled economic growth and a massively expanding ecological footprint. The critical import of degrowth proceeds from the suggestion that we humans will no longer be able to inhabit earth if we undermine the biophysical conditions for our continued existence. Degrowth is not a single manifesto, but its diverse conceptualizations draw upon an identifiable constellation of analytic concepts and normative insights. Advocates point to paradoxes of technical solutions to environmental problems, and, while consistent with a general notion of "sustainability," proponents do not agree that we need more sustainable "development" (see Demaria et al. 2013 for a helpful review).

As degrowth is a normative project concerned with how to better coordinate our habitation of this sphere to which we seem bound, it raises questions concerning distributive injustice in the global inequities that characterize people's access to productive biophysical resources. A number of contributors to a recent volume on degrowth suggest that some kind of redistributive policies will be necessary if we abandon the promises of "growth" that have been instrumental to quelling distributive justice claims (Alexander 2015: 146; Asara and Muraca 2015: 170-171; Farley 2015: 51; Kallis et al. 2015: 10). Several conversations propose radical transformations in property relations as part of degrowth efforts, as I discuss in the next section. What might such a politics look like? Which normative visions might be privileged?

In this context, I wish to draw on my research with different squatter and land rights movements in the cacao lands of Bahia, Brazil-including a few things I have learned from grassroots members of the Landless Rural Workers' Movement, or MST (Movimento dos Trabalhadores Rurais Sem Terra)_to offer some ideas about property, justice, and access to resources that degrowth conversations invite us to consider. As rural people around the world have often been the objects of intervention and reform by political movements of all stripes, I believe that attempting to explore these issues from their standpoint can help raise some critical 
questions that scholars and activists in the degrowth movement might consider. How do different distributions of property and productive resources shape people's involvement in growth processes? Are some property arrangements more or less amenable to degrowth? My current (perhaps dissatisfying) answer to the second question is that it depends, as multiple property arrangements may be drawn into processes of accumulation. Elsewhere, for example, I have examined how "collective" ownership in local MST settlements became involved in patterns of asymmetrical accumulation and distributive injustice (DeVore 2015). These and other historical circumstances informed many community members' demands to decollectivize and decentralize ownership. In this contribution, I examine the claims that Brazilian squatters in this region make to agroforests and natural springs to show how their private property claims are intersected by public interests and collective practices. By showing how these forms of property intersect, my aim is to move beyond appeals to reified property categories as providing possible answers to the second question. With respect to the first question, I conclude with the brief suggestion that efforts to democratize property may hold implications for degrowth and broader efforts to create livable, equitable, and ecologically sustainable societies.

\section{Cold War antinomies, property analysis, and progressive politics}

Especially in the last century, the terms "private" and "collective" were often used to characterize ostensibly conflicting regimes of property that seemed to map onto opposing geopolitical regimes. Hann (2000: 1-2) characterizes this habit of thought as an ethnocentric "European dichotomy, either individual or collective, [which] continued to dominate popular and academic thinking about property in the age of the cold war, since this was central to the self-definitions of the rival superpowers." In the arenas of $20^{\text {th }}$ century state politics and policy, different but equally radical measures to either "collectivize" or "privatize" resources proceeded with equal degrees of self-certainty-often with disastrous results for those populations that were taken as objects of reform (Scott 1998). As Hann suggests above, scholarly production also reproduced the divisions of Cold War politics. Hardin's (1968) influential "Tragedy of the commons," for example, influenced conservative schools of thought that would promote "exclusive [private] property as the only rational tool for resource management" (Locher 2013: 7-8, my translation). Empirically oriented research that came in response showed that common property has worked well under specific social and historical circumstances (McCay and Acheson 1987; Ostrom 1990). This work did not conclude, however, that common property was a cure-all, or that private solutions to different resource problems were never appropriate (Ostrom 2000; Ostrom et al. 2007).

One significant upshot of this scholarship was to focus property analysis on those socially and historically specific bundles of rights and powers that different people (e.g., "users," "owners," "tenants," etc.) exercise in their access and control over diverse resources, or various aspects of the same resource, at different places and over time. This "bundling" approach was developed through interacting trends in property jurisprudence (Grey 1980; Hohfeld 1923; Honoré 1961) and economic anthropology and sociology (e.g., Gluckman 1965; Goody 1962; Hann 1996; Malinowski 1935; Mayer 2002; Ribot and Peluso 2003), which together describes complex intersections of what may be thought of as "private" and "collective" forms of property. This scholarship undermined any reified distinctions between opposed property "regimes," and highlighted the ways in which different ideas and dimensions of property, as Bollier (2007: 38) suggests of commons and markets, may be thought to "interpenetrate each other and perform complementary tasks."

Beitl (2012: 96) notes that property analysis and political ecology frameworks can be drawn into fruitful dialogue as both are concerned with social mediations of resource access that are variously "cooperative, conflictive, hierarchical, divisive, power-laden, political, and constantly in flux." Beitl (2012) and Meilasari-Sugiana (2012), for example, examine the dynamics of access and control to mangrove resources in reconstituted "ancestral" territories and community-based stewardship programs. MeilasariSugiana (2012) draws attention to ways in which the benefits of community-based programs may be captured

\footnotetext{
${ }^{2}$ Waldron (1988: 49) draws on Wittgenstein's (1953) notion of a conceptual "family resemblance" to argue that the bundling approach should not mean abandoning intuitions about the varying degrees to which property is private, public, common, collective, and so forth.
} 
by traditional authorities that are often invisible to outside observers who have undifferentiated understandings of "community." Beitl (2012), on the other hand, describes a "tragedy of common property rights" (2012: 107) after "non-affiliated cockle collectors," with long histories of using local mangrove resources, become excluded from these resources on the basis of their inability to ground their claims in "ancestral" territorial rights. Studies such as these draw attention to the potentially exclusionary outcomes of well-meaning efforts aimed at social inclusion and sustainability, and they highlight the importance of situated analyses that investigate, rather than proceed from, categories and relations of property.

Degrowth conversations, and progressive politics more broadly, can draw on these different frameworks to circumvent old antinomies between private, common, or collective property. This seems especially important whenever calls are made to promote or abolish some form of property over others. Indeed, Alexander notes that some commentators (e.g., Fotopoulos 2007) suggest that a potential degrowth transition will "necessitate the abolition of private property and the institution of some form of state socialism" (Alexander 2011: 85). Other commentators suggest that the activity of "commoning" is "noncapitalist" and will thus "diminish the role of private property" (Kallis et al. 2015: 10) in a degrowth society. ${ }^{3}$ Elsewhere, in his important analysis of the "property economy," van Griethuysen suggests that "alternative institutional arrangements to the private property regime, such as state property and common possession, could be elaborated and implemented" (2012: 268)—perhaps under a nascent "global, collective authority" (2012: 266). ${ }^{4}$ In a different but influential context for degrowth conversations, Escobar suggests that the "logic of collective ownership of territory is more attuned in principle to this perspective [of biodiversity conservation and sustainability] than that of individual property, which tends to lead to greater fragmentation of habitats and communities" (2008: 153). Deriu (2012: 559), finally, suggests that a renewed focus on the "commons" will help to raise doubts about "the dominant conception of possession and private property." But do the multinational corporations that are one of Deriu's main concerns (2012: 556) represent a dominant conception of "private" property? Corporations, after all, are collectively owned enterprises. ${ }^{5}$ And why is the habitat fragmentation that Escobar associates with individual property inconsistent with the "habitat patchiness and heterogeneity and [thus] biological and genetic diversity" that he associates with collective territorial ownership (2008: 153)? ${ }^{6}$ What is it about "private property," more specifically, that might be diminished or abolished?

Alexander (2011: 85-90), by contrast, draws explicitly on the bundling approach to point out that the general concept of private property-just like any notion of common or collective property-is indeterminate apart from its historical specification in actual social practice. This perspective leads him to suggest that legal and institutional reforms of private property have been "inadequately explored, or insufficiently understood" (2011: 85) when considering the prospects for degrowth. My own research takes Alexander's position seriously, and draws upon "bundling" and political ecology frameworks, to resist the tendency to think about property in dichotomous ways.

\section{Alternate histories of "private" property}

Making space for private property at the round table of the progressive politics may be an uphill battle, as the very idea has a troubled history with the political left (Scott 2012). When considering private property, some scholars may have in mind a version of William Blackstone's $18^{\text {th }}$ century definition as that "sole and despotic dominion which one man claims and exercises over the external things of the world, in

\footnotetext{
3 The idea of "commoning" looks to those social interactions by which common resources are brought about (Helfrich and Bollier 2010). I will suggest that something like commoning is precisely what is involved in bringing about the "private" properties I describe below.

${ }^{4}$ van Griethuysen's (2012) analysis is concerned with the use of legal property titles as collateral for credit. This relates to the kind of property economy envisioned by de Soto (2000), which would purportedly release the "dead capital" that is latent in assets held by the world's poor. van Griethuysen highlights the risks that this particular configuration of private property has for debt, foreclosure, property consolidation, and thus social exclusion.

${ }^{5}$ Ferguson recently makes this point $(2015: 51,178)$.

${ }^{6}$ Walters (2012) and Hecht (2004: 70-71, 92-93) review a range of literature and evidence that casts doubt on the claim that there is a principled pairing between property forms and conservation outcomes.
} 
total exclusion of the right of any other individual in the universe" (Blackstone 1979[1765-1769] cited in Rose 1999: 601). ${ }^{7}$ The exclusionary and anti-social overtones are not difficult to hear in this definition, and they resonate with familiar critiques of private property as an instance of what Macpherson (1969) calls "possessive individualism." My research with land rights movements in Brazil suggests a broader range of historical circumstances under which claims to private property may emerge. As I show below, these claims interweave characteristics of private, public, and common property together with ideas of personal autonomy, social solidarity, and collective action. ${ }^{8}$

Let me clarify why I am interested in unpacking these questions as a way of introducing the ethnographic context that will follow. Elsewhere (DeVore 2015), I examined the appearance of what may be characterized as a "master/subject model" (Fraser 1997) in the collective property relations of several land reform communities affiliated with Brazil's Landless Rural Workers' Movement (MST). Shortly after these communities formed in 1997, members of the local MST leadership implemented (sometimes forcefully) collective forms of production and ownership. Work relationships in these communities quickly became intersected by hierarchical forms of authority, and powers of exclusion, that were disproportionately controlled by members of the local leadership. This situation also highlighted internal patterns of asymmetrical accumulation that further strained relations within the community (DeVore 2015: 1218-1219). In response to these circumstances, settlers in several MST communities organized themselves in order to force the division of collective lands into individual family holdings. In other communities, the settlers not only resisted collectivization, but resolved to expel the leaders from their communities and end their affiliation with the MST altogether.

To build an analytic framework for understanding these episodes, I drew upon Nancy Fraser's notion of "participatory parity," focusing on what Fraser describes as an "objective" (or material) condition that she distinguishes from an "intersubjective" condition (DeVore 2015: 1204-1205). According to Fraser (2001: 36), the objective condition is fulfilled when people control an independent and secure livelihood, access to which does not depend upon an authoritative and controlling other. With legal practices like $19^{\text {th }}$ century "coverture" laws in view, ${ }^{9}$ Fraser developed this idea by considering how the threat of material destitution could reinforce gender hierarchies by curtailing women's ability to exit from problematic domestic relationships. ${ }^{10}$ When considered from this standpoint, the motivation behind the MST settlers' decision to divide the land becomes clear: their experience with collective ownership, which was shaped by community institutions that reinforced power asymmetries between leaders and settlers, fostered the reproduction of social hierarchies that were structurally analogous to those with which many settlers had been familiar in plantation contexts. Ribot and Peluso provide succinct language to characterize the transposition of these structural relations: "Some people and institutions control resource access while others must maintain their access through those who have control" (2003: 94, emphasis in original). On Fraser's model of participatory parity, therefore, collective ownership —at least as it was practiced in these communities-undermined the "objective" condition of participatory parity.

\footnotetext{
${ }^{7}$ Rose (1999: 604) suggests that Blackstone's view of property was not divorced from consideration of "social and political obligations" that could override claims to exclusive domain, and that the "Exclusivity Axiom" was for Blackstone more a "rhetorical figure describing an extreme or ideal type rather than reality" (Rose 1999: 604). Indeed, it is not clear that a purified regime of "absolute" private property has ever existed except in this rhetorical universe. Hess and Ostrom (2007: 8) seem to imply that what may begin as an analytic move to classify "all of the goods that might be used by humans as either pure private or pure public" ends up as a category mistake guiding the search for actually purified forms of property.

${ }^{8}$ Kingston-Mann (2006), McCandless (2010), and Mayer (2002) offer fascinating cases from the former Soviet Union, Vermont (U.S.A.), and Peru that suggest similar intersections to those described here. Mayer suggests, moreover, the internal complexity of Andean "collective organizations that respect the autonomy of the household" (2002: 41-42) may help to explain their success in contrast to the failures of other collectivist projects in Peru and elsewhere.

${ }^{9}$ Coverture refers to those $19^{\text {th }}$ century British laws by which women's legal personalities, and rights to hold property, were subsumed by the legal personalities of male heads of household. See Fraser and Gordon (1994) for relevant discussion.

${ }^{10}$ Agarwal's (1994) work in rural South Asia, which examines the relation between domestic violence and women's status as property owners, parallels many of Fraser's claims.
} 
Settlers in these MST communities want many of the legal and ethical trappings often associated with private property: security, land titles, and the power to exclude those who might try to control their labor and leisure. ${ }^{11}$ This relates to many settlers' yearning for a "freedom," as Wolford observes, that "meant freedom from control (even [sometimes] the MST's control)" (2006: 350). What is also important to highlight, however, is that their response to their situation was collective. In confronting the leadership and forcing the division of collectivized land, community members first had to build the intersubjective conditions that were required to undertake the collective actions that helped them achieve private goals that they shared in common (DeVore 2015: 1221). Their social action, in other words, was shot through by different private, individual, public, collective, and common dimensions.

This episode helps us to consider "private" property in a different light. It also highlights the kind of historical episodes informing critical social theories that make a normative virtue of resisting and excluding unwanted transgressions into social and subjective space. ${ }^{12}$ MST settlers' understandings and demands for private property has little to do with familiar justifications (e.g., utility maximization, efficiency, greed), and has even less to do with those historical episodes when it was supposed to emerge and expand (e.g., English enclosures, primitive accumulation, colonial dispossession). If they appear as "individualists," their individualism has little to do with neoliberal or capitalist ideology, but is rather a situated and shared response to renewed experiences of hierarchy, insecurity, and exploitation.

In what follows, I turn to the private property claims that squatters in this region of Brazil make to natural springs and agroforests, which, as the outcomes of specific social interactions within the biophysical landscape, draw together intersubjective relations, collective actions, and claims about the public good. I focus on communities that neighbor the MST settlements briefly described above, including a mixed agricultural community called Pequi, and an independent squatter community called Nossa Senhora. Pequi extends up the side of a hill situated at the intersection of a few dirt roads that run between several local plantations. Just up the road, the squatter community at Nossa Senhora began as a group of about fifteen families - many of them landless residents at Pequi-that began to occupy the forests of an old plantation that was abandoned in the late 1970s. While there is a longer history to this occupation, these families began to physically occupy the forest in $1997 .{ }^{13}$ The first case I wish to consider is concerned with the provisioning of water through natural springs, which draws together private property claims, public infrastructures, social institutions of trust, friendship, and ideas about the public good. The second case focuses on the sociality and labor involved in the transformation of forest into agroforest. These agroforests are also claimed as private property, but, at each turn in their formation, these properties similarly rely upon a common intersubjective infrastructure.

\section{Water, springs, and hills}

Natural springs (nascentes) emerge at various turns and crevices in the region's hills, and gradually combine to form smaller streams and eventually rivers that make their way to mangrove estuaries on the southern coast of Bahia. The distribution of springs in these hills, which rise to nearly 400 meters in some places, forms something of a rhizomatous structure. ${ }^{14}$ An afternoon walk through the forests, farms, and

\footnotetext{
${ }^{11}$ Lund makes the important observation, however, that it is not the character of being '"private' which makes a land holding certain" (2001: 158), but rather the quality of social and institutional relations of recognition. Certainty is thus neither a necessary nor an exclusive predicate of "private" property, but rather a historically contingent incident that may occur in different arrangements of property, tenure, and access.

${ }^{12}$ Ideas of self-sovereignty, self-ownership, and "property in the person" have arisen in diverse feminist, Marxist, libertarian, and anarchist debates that are variously concerned with human emancipation from social domination (e.g., Cohen 1995; Pateman 2002). Rose captures this idea in the notion that each person needs a "small domain of complete mastery, complete self-direction, and complete protection from the whims of others" (Rose 1999: 604).

13 The background story to these communities appears in DeVore (2014: 1-7, 637-644). In DeVore (2015), Nossa Senhora appears as "Settlement 4" while Pequi appears very briefly under the name "Mixed Agricultural Community."

${ }^{14}$ On the basis of detailed landscape analysis, Kevin M. Flesher (personal communication) suggests that no point in the landscape is more than 400 meters from a waterway. In 2012, I surveyed 34 farm families who reported on the presence of water at their different landholdings. Of these, 31 reported having some source of on-site water, whereas only 3 reported none. The 31 families reported access to water on 61 spatially discreet plots, 56 of which included on-site farm
} 
plantations that form a patchwork throughout these hills almost invariably leads to numerous waterways and frequent encounters with potable water (Figure 1).

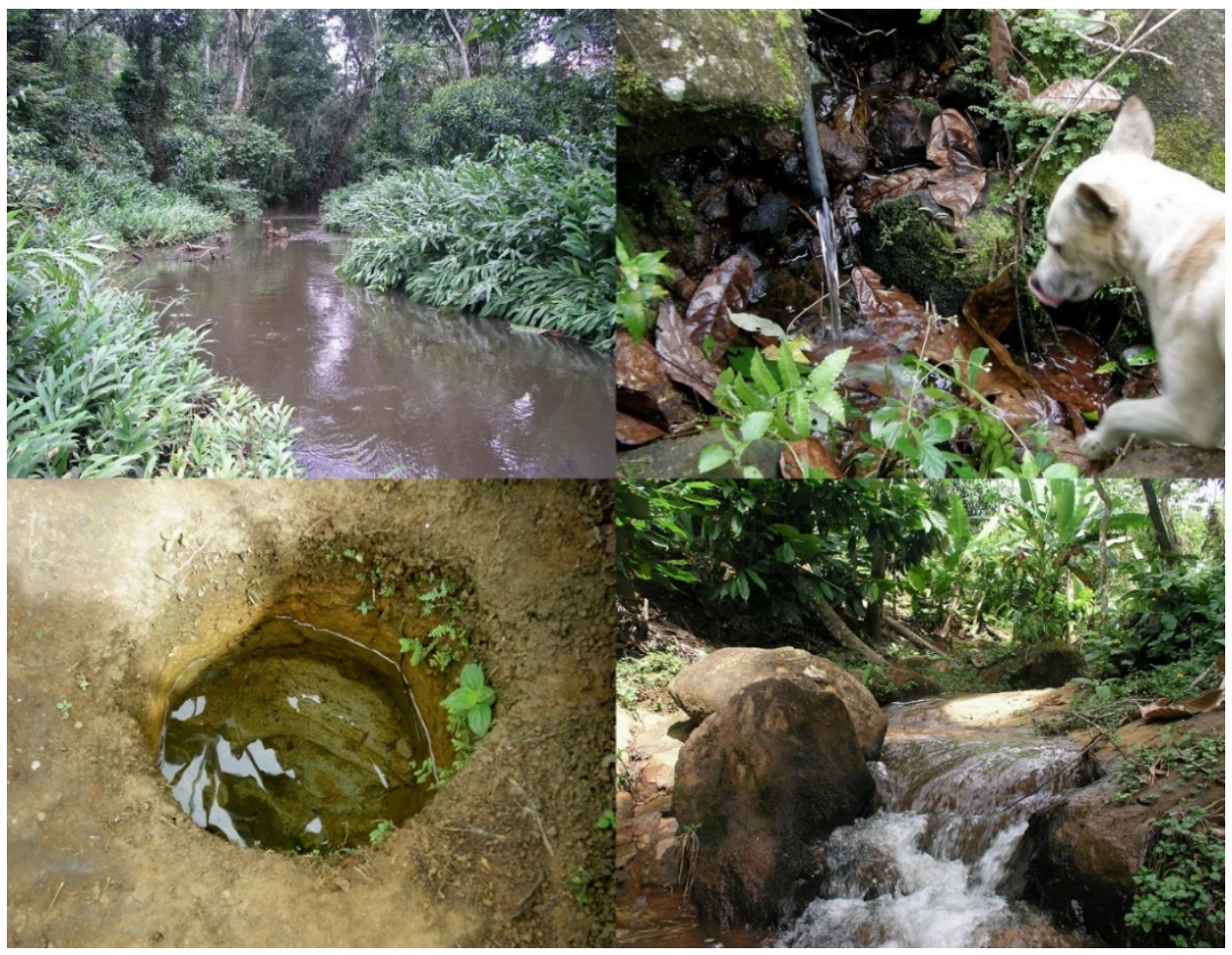

Figure 1: a) A river that marked the former property line at Nossa Senhora (top left). b) Potable water emerging from rocks (top right). c) A small poço, or hand-dug well, near the banks of a small river (bottom left). d) A small stream running through a farmer's cacao grove (bottom right). ${ }^{15}$

The smallest natural springs emerge under the cover of forest that helps protect and sustain the flow of water. Local users often make minute infrastructural modifications to these sources in order to make the water more easily drinkable (Figure 2).

In local land markets, or for squatters searching for stretches of forest to occupy, the presence or absence of water greatly affects the desirability and value of particular locations. Remnants of historical structures, such as old house sites or manioc flour mills (casas de farinha), are frequent found near such water sources (Figure 3). For small farmers with limited financial resources, an on-site source of potable water is a crucial part of their livelihood and work. The costs of installing piping infrastructure to bring water in from distant sources are often prohibitive.

access. Of these, 28 had natural springs (nascentes); 23 had streams (riachos); one (1) had both a natural spring and a stream; one (1) had both a stream and a small hand-dug well (poço); one (1) had a small hand-dug well; one (1) had piped water; and one (1) did not specify the source.

${ }^{15}$ All photographs in this article are by the author. 


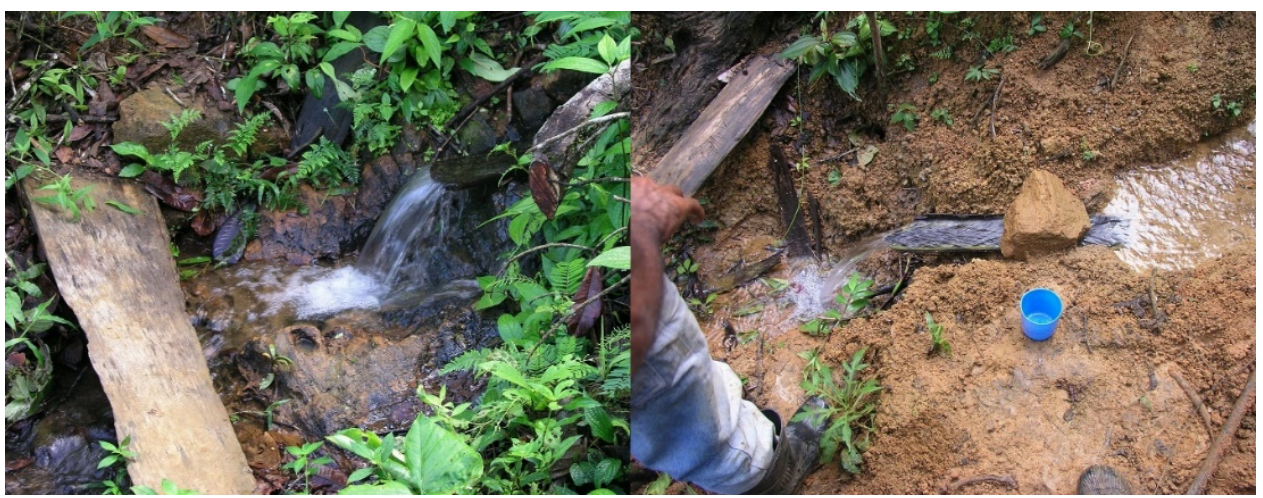

Figure 2: Flat rigid pieces of wood, tree bark, hard plastic, PVC pipe, or pieces of rubber hose (see Figure 1b) are installed at small dips in the ground. This creates a temporary gap (i.e. a fountain) between the water and the ground upon which it flows, making room to insert cups, leaves, or one's hands to collect water.

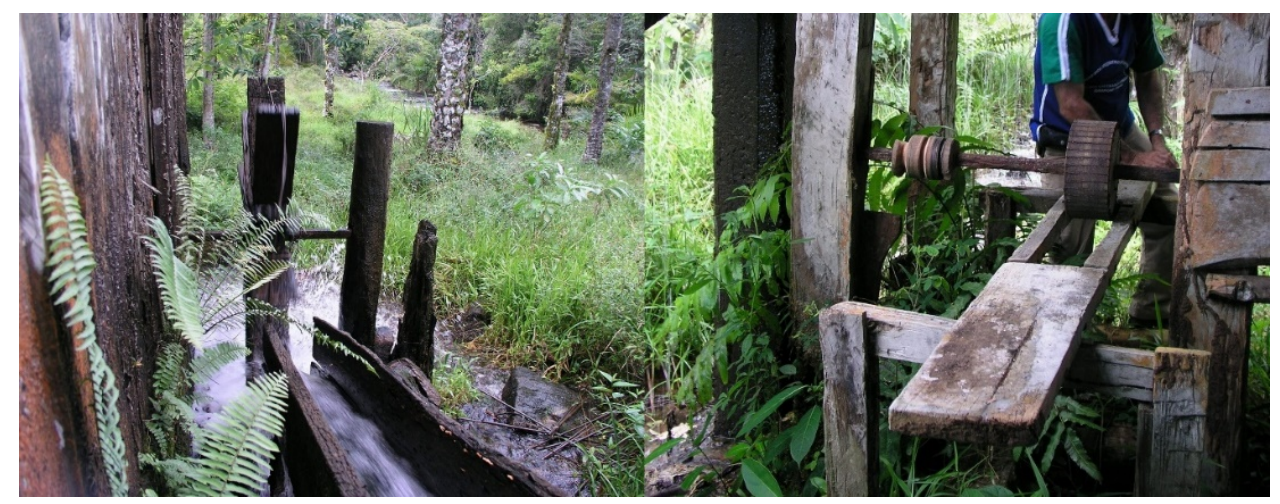

Figure 3: a) Water is channeled onto a wooden mill wheel (left). b) The mill powers a grinder used to process manioc roots into a coarse flour (right).

In Bahia's cacao lands, while water is hardly scarce, varied situations within the landscape do necessitate shared water resources. Families living at Pequi draw on water sources that originate on privately held plantation and smallholder lands. In 2002, there were two main sources of water at Pequi. The first source was a relatively productive open spring situated just below the community on land that belonged to a neighboring plantation. This spring was, by common agreement, a place where residents at Pequi, many of them landless day laborers and plantation workers, could go to procure water or bathe.

The second source of water was piped from another nearby spring to a bica de agua, or water spigot, that entered the lower part of the community. Because the source spring came from below the community, gravity prevented the spigot from being placed higher up in the community. Consequently, accessing water was particularly difficult for families living up on the hill. During this time, it was common to see women, many with children in tow, congregated around the spigot with large basins of clothes and dishes to be washed, or going to fetch water in large containers that they carried balanced upon their heads. This was not easy labor for the women and children who had to undertake it.

After 2002, a new water infrastructure was built from a different spring situated on another hill that rose higher above the community, in part through the initiative of a now disgraced city councilman. The spring's source was situated on the lands of a local smallholding family, and was piped into the community where it was collected in a large storage tank. Water from the tank was, in turn, connected to a subsequent 
network of smaller grade PCV pipes and fittings that were buried in the ground on their way to homes at the top of the hill (Figure 4). Although the city councilman who helped establish the project is no longer active in municipal politics, one woman at Pequi explained that if he ever needed her vote, he could count on hers. The new infrastructure that piped potable water directly into her home provided immense relief to her daily water-related work routine, which was previously centered upon the communal spigot down below. As a result of this project, use of both the communal spigot and the open spring on the nearby plantation lands began to diminish.

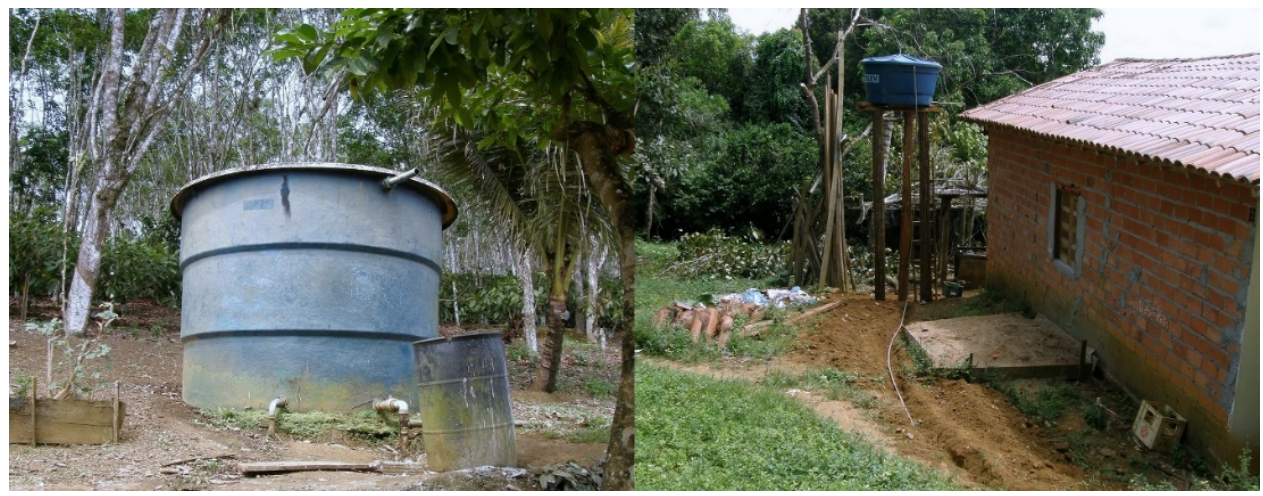

Figure 4: a) The large water storage tank that connects to multiple houses (left). b) Smaller water storage tank connected to the adjacent house. The tank is placed upon stilts to create gravity fed water pressure. The small PVC piping, and ditch where it was to be buried, are visible in the foreground (right).

Squatting in this region proceeds on the basis of labor, occupancy, and possession, and squatter claims resemble family freeholds or "individual" private property. ${ }^{16}$ Any person can become the socially and (at least potentially) legally recognizable owner (dono) of those sites where she or he squats, clears, and cultivates, as I explore further in the next section. Because of the way in which squatter families occupy the landscape, and because of the wide distribution of springs, families' property claims also incorporate springs. Indeed, squatters often seek to integrate springs into their land claims together with small stretches of forest that help protect the water source. One farmer, for example, explained that he hoped to buy a small fragment of forest adjacent to his farm so that he could protect a spring that ran through his farm from drying up. As long as that small bit of forest was under the control of others, he explained, there was a risk that they might cut it down for other purposes and diminish the flow of water.

As this last example illustrates, springs do not occur on all farms, and the topographic situation of different land claims can lead to both resource inequalities and opportunities. Some families whose lands are intersected by shallow ravines have dug small earthen dams to create small pools and ponds (represas) for raising fish, while others have built small dams using bricks and cement (Figure 5). Other families' lands are crossed by larger streams. While this water is not safely potable, it does afford a practically unlimited source of water for washing clothes, dishes, or bathing. When these heavier flows of water cascade over sharp drops in the landscape, some families have been able to fashion homemade hydroelectric mills that can generate small amounts of electricity for the household (Figure 6). These are also good locations for fish traps (Figure 7).

\footnotetext{
16 The term "individual" is indeterminate and could mean individual person or individual household. The dynamics of paternal authority, however, often (though not always) means that male heads of household enjoy disproportionate control and decision-making over productive resources. Men's legal names, for example, often appear in legal documents related to land, although Brazilian civil law provides for equal partible inheritance to all family members.
} 


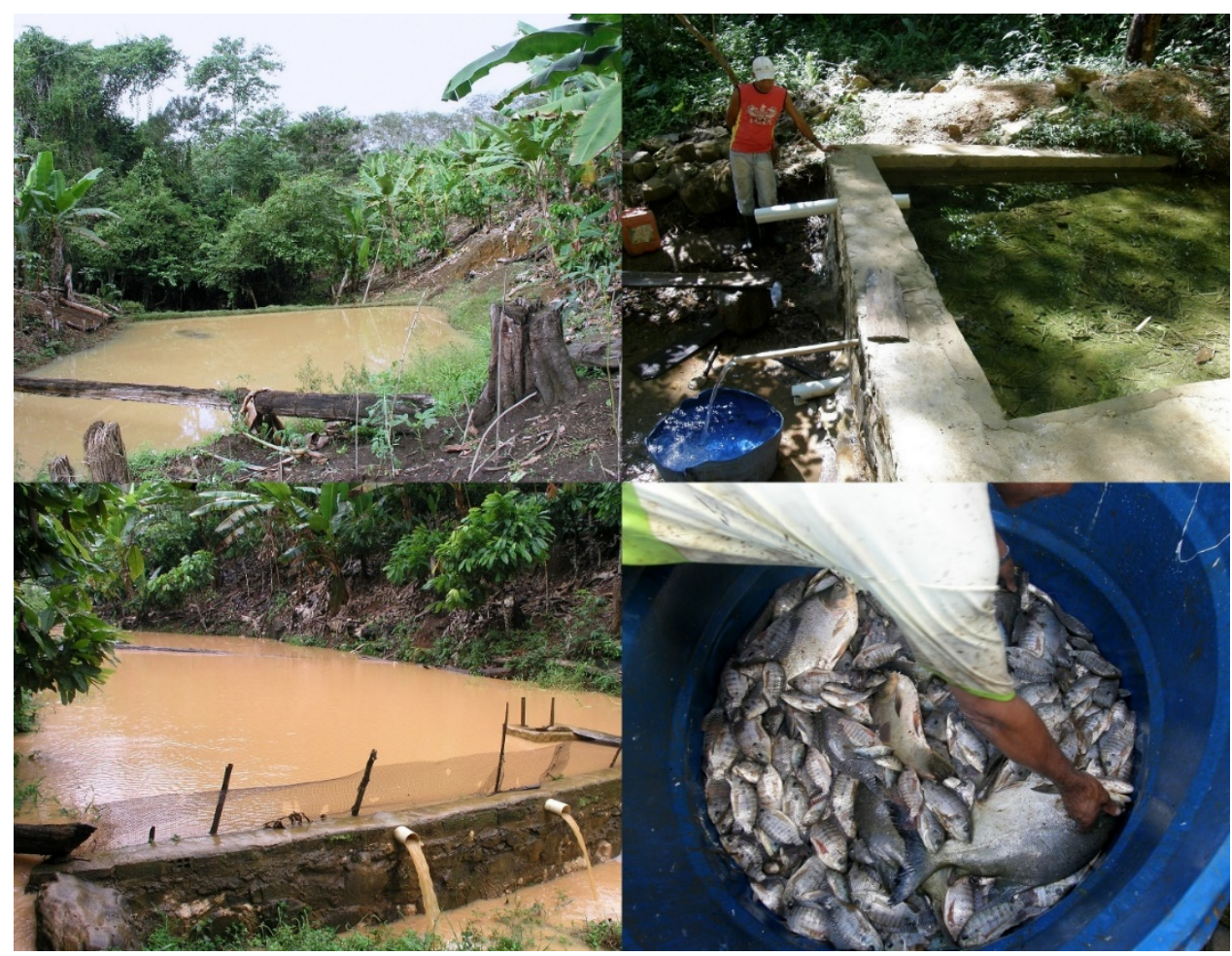

Figure 5: a) Fish pond made from a hand dug earthen dam (top left). b) Potable water reservoir built from bricks and concrete (top right). c) Fish pond made from a brick and concrete dam (bottom left). d) Fish harvest. Mostly tilapia and a few tambaqui (Colossoma macropomum) (bottom right).

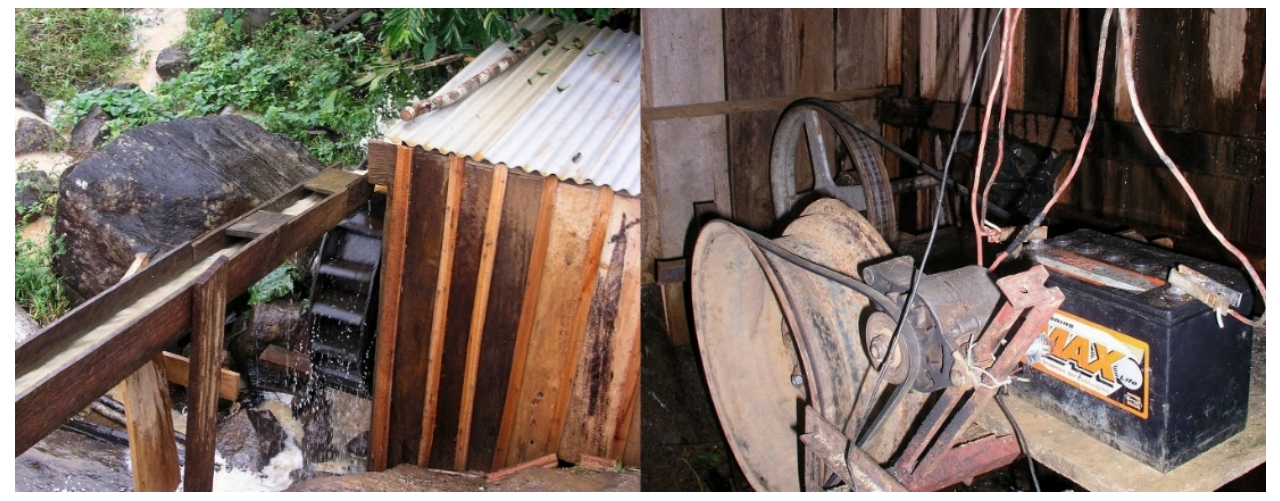

Figure 6: a) Water being channeled onto a homemade hydroelectric mill wheel (left). b) Power from the mill charges car batteries that provide a modest electrical supply to the home (right). 


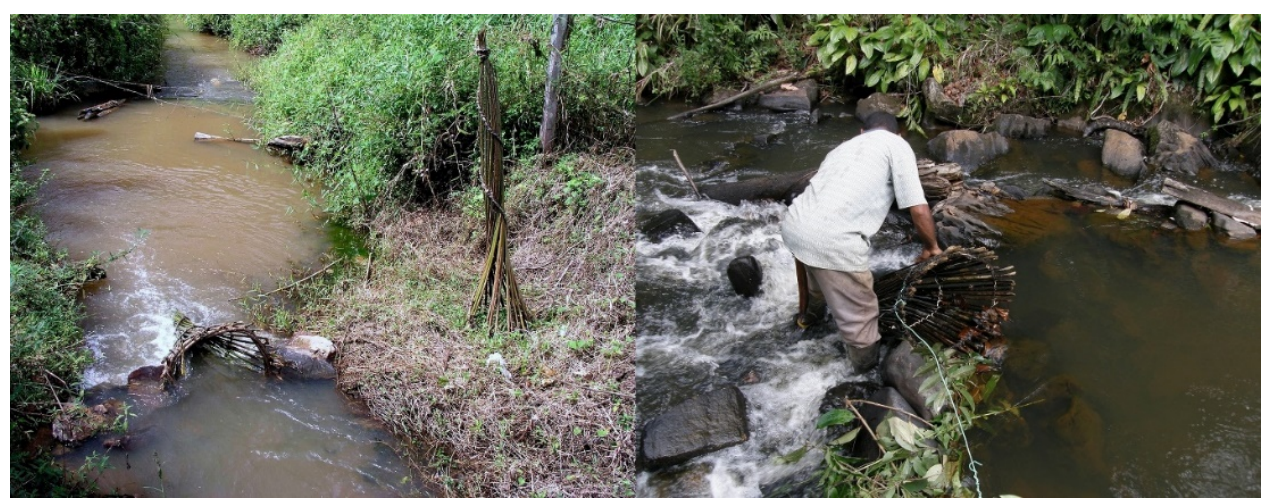

Figure 7: Conical wicker fish traps that locals call a jiqui (alt. jequi) are placed at choke points that form between rocks in streams and rivers. These traps are ideal for use after rainfall as stronger currents both wash fish and crustaceans into the trap while helping to prevent their escape.

The lack of potable water does pose problems for some households, however, especially when they are situated at greater distances from communities like Pequi where water infrastructures are available. ${ }^{17}$ One squatter family facing such a water dilemma found a solution by appealing to the manager of a neighboring plantation. The plantation manager helped the family run a long hose from a spring situated high up on the plantation land in order to transport water directly into the family's home. In another case, a family living on a local MST settlement solved the same problem by coordinating with another local family that held a small spring higher up on a hill. One member of the family that benefitted from this arrangement explained that they had solved their water problem "by means of friendship" (através de amizade). Both cases provide examples of what Helfrich and Bollier (2015) call "commoning," and appeal to the formation of a shared ethos of social trust and mutual care. In each case, this ethos served as an immaterial good held and sustained in common, and which aimed at the provisioning of various private goods. In short, while springs were treated as a form of property under the ownership and stewardship of individual families, these resources were subject to claims of a publicly shared ethos that involved local landless families, squatters, and plantation managers. The common solutions they found to these problems were often small in scale (often involving two households), sensitive to the character and quality of social relationships, as well as different situations within the physical topography.

There were negative consequences for those who violated this ethos characterized by trust and care, which had become institutionalized into a tacit public expectation. In 2009, for example, the plantation situated just below Pequi community was sold to a new owner. Shortly thereafter, the new owner began putting up new fences along the perimeter of the old plantation. These fences closed off access to the spring located on neighboring plantation land, which had already fallen into relative disuse, as well as a soccer field that had been opened on the plantation's land years earlier with the verbal permission of the former owner. Community members, and especially the young soccer-playing men, were angry. Because the same plantation also depended on water from the new infrastructure that was built in the community after 2002, some of the community members at Pequi threatened to cut the pipes that supplied the plantation with water, as the new owner had violated a long-standing relation of access between families at Pequi and the plantation.

Around 2009, other efforts were undertaken by an organization that was funded by the late Norberto Odebrecht, which sought to develop a comprehensive conservation plan for the region's entire watershed.

\footnotetext{
${ }^{17}$ In addition to water, electric infrastructures are more readily available at Pequi.
} 
Among other things, ${ }^{18}$ this project proposed to widen and asphalt the extant dirt roads throughout the region. This road-building project threatened to encroach upon a number of small cacao farms, as well as houses in communities like Pequi that were built right at the margins of existing roads.

When this project was announced in 2009, one local farmer became especially worried as the only good source of water at his family's farm was from a spring a few meters from one road (Figure 8). His family depended on this spring for water, and had taken care to preserve the forest just above it. A significant stretch of this remaining forest, along with the spring itself, would have been destroyed by the new roadbuilding project. Annoyed by the prospect that Odebrecht might enclose even more land in the region, ${ }^{19}$ this farmer angrily asked, "How many people have quenched their thirst from that spring!?" In this comment, he was pointing out that, beside his own family, many of the region's plantation workers and day laborers also depended on this spring for drinking water.

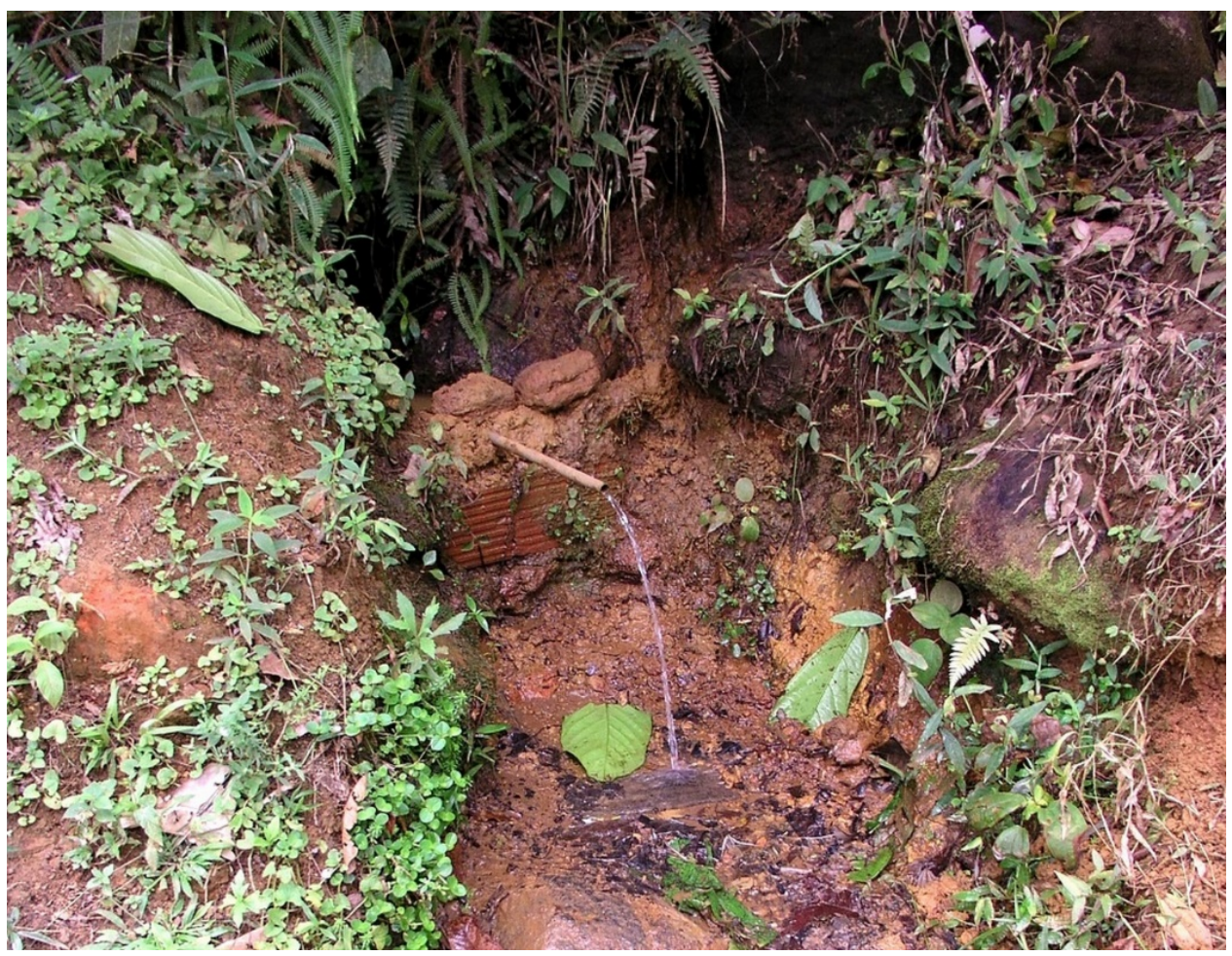

Figure 8: The storied fountain that was threatened by the road-building project.

Indeed, the history of this particular spring was interwoven with the personal stories of those who in earlier decades had migrated in search of work on the region's plantations. One former plantation worker who had come to the region in 1980, and who now lives on a local MST settlement, recalled quenching his thirst from this spring when he first arrived in the region on foot:

\footnotetext{
18 This project sought to reshape community institutions, local productive activities, and proposed to build a large hydroelectric dam that would have significantly transformed the region.

${ }^{19}$ Many local people attribute personal responsibility to Norberto Odebrecht for a land grab that occurred in the region between the 1950s and 1970s. See DeVore (2014), especially chapters 4 and 5.
} 
In 1980, I went to work at Suor plantation. . . . I barely knew the region, and there I was this crazy Sergipano coming from far away. ... W Well, I walked by here. They told me:

There's some good water down there that we can drink.

Where at, man?

There's water-down below.

We even filled up some containers that we took with us - some containers of water. And then I went to work at Suor plantation. I barely knew the region.

This brief narrative highlights an interesting aspect of the kind of public "community" that has formed around this particular spring. While commons are often form by concrete communities in relation to a definite resource that they manage jointly through shared conventions, the nature of "community" in this case is decidedly indeterminate. While it is partly comprised of a definite set of people (e.g., the owner-stewards), it also looks toward future laborers, wayfarers, passers-by, and other thirsty newcomers who are not native to the place, but who are welcome to quench their thirst nonetheless. This anticipation and concern for these potential but not-yet-actual others is partly what informed the anxiety of the family that owned the spring, which was threatened by the proposed new road. ${ }^{20}$ Fortunately, the road reconstruction project has yet to materialize, although the threat lingers.

\section{Trees, forests, and agroforests}

As suggested above, squatters in the region create private properties on the basis of labor, occupation, and possession, which instantiates a local "labor theory" of property. The labor theory of property, which is commonly associated with John Locke's political philosophy, suggests that people may claim property in those things upon which they have labored. Local practices of property-formation in Bahia draw upon similar intuitions about labor and possession together with legal concepts like "usucaption" that can be traced as far back as Roman civil law. The Portuguese term usucapião, which is derived from the Latin usucapio (i.e. to capture or take possession by continuous use and enjoyment) is creatively rendered by many local people as uso-campeão. This roughly translates as "use champion," perhaps by analogy to victory in a soccer match.

Whereas natural springs are less the products of human labor than they are objects of stewardship and care, the gradual process by which squatters transform forest into agroforest is an outcome of intensive human activity that draws together, and interacts with, various biological and ecological processes. The properties that result are reckoned as "private" insofar as they accrue to the people who make them, but to characterize them as the "sole and despotic dominion" of some lonely individual would be to misrecognize their connection to the social world. Indeed, at every turn in the formation of these claims, their viability turns upon the social recognition that some person or some family has labored in some particular place, or else aims to do so in a plausible future. ${ }^{21}$ This recognition, which is a kind of respect paid to the labor processes and projects of others, constitutes what then appears as the "exclusion" and exclusivity of "private" property. In this sense, exclusion is a social value. ${ }^{22}$

\footnotetext{
${ }^{20}$ Elsewhere I describe a parallel situation of "generosity without esteem" in which "generous activity is oriented toward a merely potential other and without any guarantee that the generous action itself will ever be widely recognized or even recognized at all" (DeVore 2014: 406-408).

${ }^{21}$ This recognition is what similarly enables families to hold small reserves of forest that are not encroached upon by other squatters.

${ }^{22}$ As I have suggested elsewhere on the basis of other evidence, "exclusion" in this context must be understood as the outcome of an intersubjectively formed "'we' that does not eliminate or conflate the 'I' and the 'you'" (DeVore 2014: 136). I take it that when one of my informants articulated an understanding of his own property as being "collective-individual"
} 
Property theory is often concerned with formed objects (e.g., coffee mugs, car parts, houses), which are identifiable through indexical markers ("That coffee is yours, this one is mine"), and may be transferred between people through different sorts of exchange. As the agroforests that people cultivate are literally a growing presence on the biosocial landscape, it is difficult to understand local property claims apart from the practice and process of making property objects. In order to convey this sense of property, we might briefly walk through the process of how claims to such objects are formed. This means that we attempt to imaginatively situate ourselves in the actual process of walking through, transforming, engaging and being engaged by a landscape in whose making we are co-participants. ${ }^{23}$

The families from Pequi inaugurated a long process of social and biophysical transformation when they began to occupy the forest at Nossa Senhora in 1997. They began this process by an initial process of demarcation, which established a projected, and literally grounded, matrix into which each family would be able to expand and cultivate in the years that they hoped would follow. They carried out these demarcations using a long rope that they had knotted at one-meter intervals in order to measure plots roughly 12 hectares in size. This might be thought of as a process of location, which involves social interaction and intersubjective coordination over a particular stretch of land that becomes the object of agricultural transformation.

Once they had completed these initial demarcations, which prefigured subsequent productive activities and coordinated normative expectations (i.e. which spaces were proper to, or to be the property of, whom), they began a process that might be thought of as situation (cf. the Portuguese term sítio). This process comes with a high expenditure of human and other energies. It begins with what is called raleamento, or the initial process of thinning the forest, which was done using some combination of machetes, axes, or chainsaws. The thinning process decouples the understory of vines, shrubs, and small trees from the larger trees that are left standing above. Destabilizing the interwoven lattice of vegetative support beneath the taller trees helps to ensures that they will fall in the felling process, which is referred to as the derruba. Depending on each family's financial situation, felling may be done manually with axes, or with a rented, borrowed, or bartered chainsaw (Figure 9). Some families, for example, might barter a valuable piece of timber from their forest plots, which they employ as a sort of natural capital in exchange for help from a family that owns a chainsaw (Figure 10).

After several weeks', once the resulting mass of vegetable matter has dried, squatters inaugurate the queima, or the burn. Local families explain that beyond releasing nutrients into the soil, burning helps to open space for work, and mitigate the hazards to human vulnerability, within a powerful and recalcitrant biophysical landscape. Farmers attempt to control the intensity of the burn by beginning before the mass of vegetation is bone dry, and by avoiding days with intense sun or wind. While burning appears as a destructive activity, people's attention to burning conditions helps them prevent extensive damage to the layer of humus and various organisms that comprise the soil (Figure 11). The burn process proceeds in two phases, including an initial general burn that is later followed by the coivara (Figure 12). In this latter process, midsized branches that remain after the initial burn are gathered into piles and burned a second time. The largest trunks are often left to decay; sometimes used, given, or sold for firewood; or perhaps cut into lumber for sale or small building projects (Figure 13).

(DeVore 2014: 702), he was contributing a novel theoretical articulation of the point that I wish to make here. See DeVore (2014: 130-147) for a more extensive discussion of squatter property, including considerations of gender, legal, and intersubjective dimensions.

${ }^{23}$ I write "walking" deliberately because the process must be understood (phenomenologically) as one that is largely undertaken while moving about on one's feet. Elsewhere, I have tried to offer a more vivid account of this process (DeVore 2014: 338-345). 


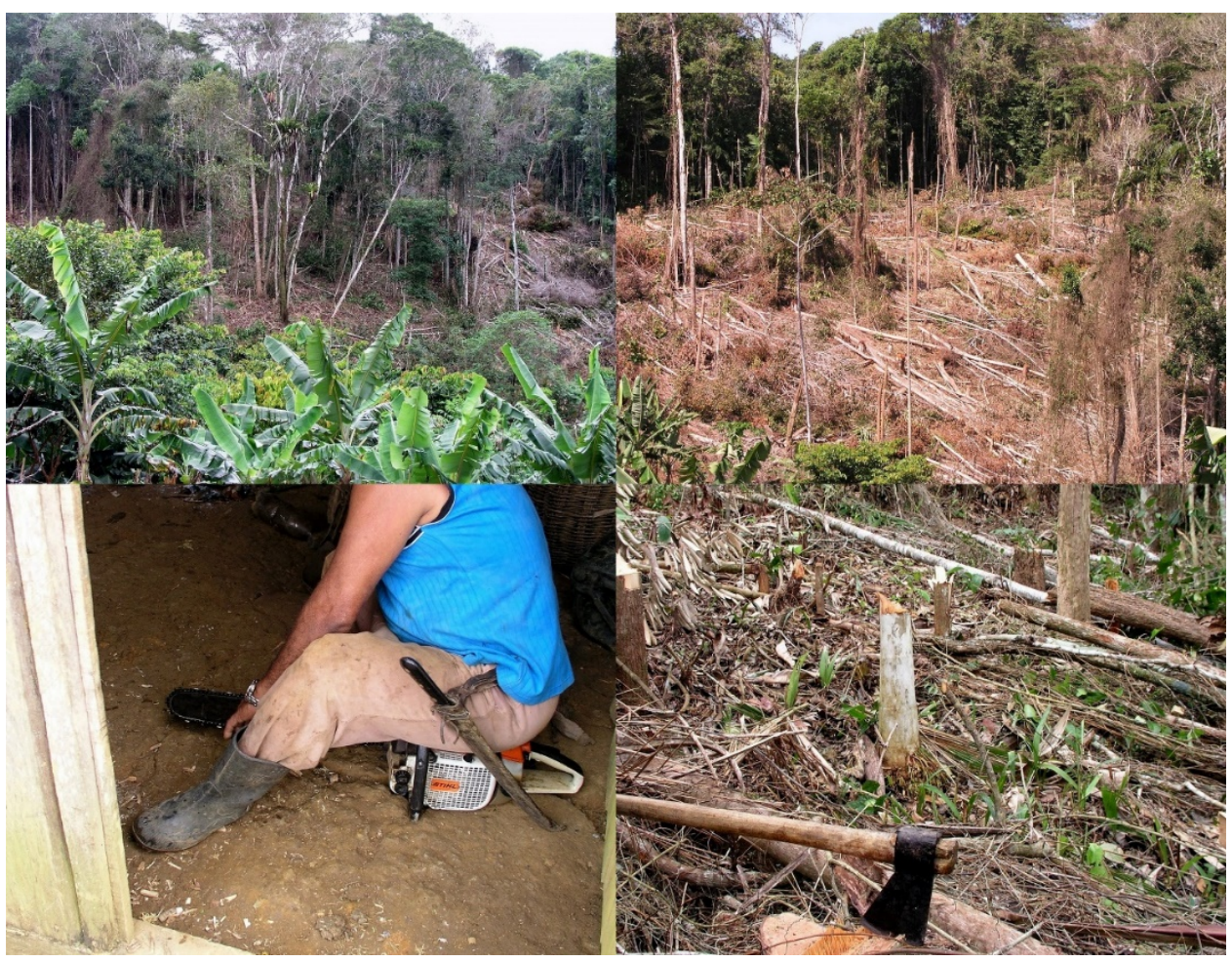

Figure 9: a) A new farm plot after the initial thinning of the understory (top left). b) The same plot of land after most of the heavy felling had been completed (top right). c) Sharpening the teeth on a chainsaw (bottom left). d) Smaller trees such as these in the center of the photograph are easily felled using an axe (bottom right).

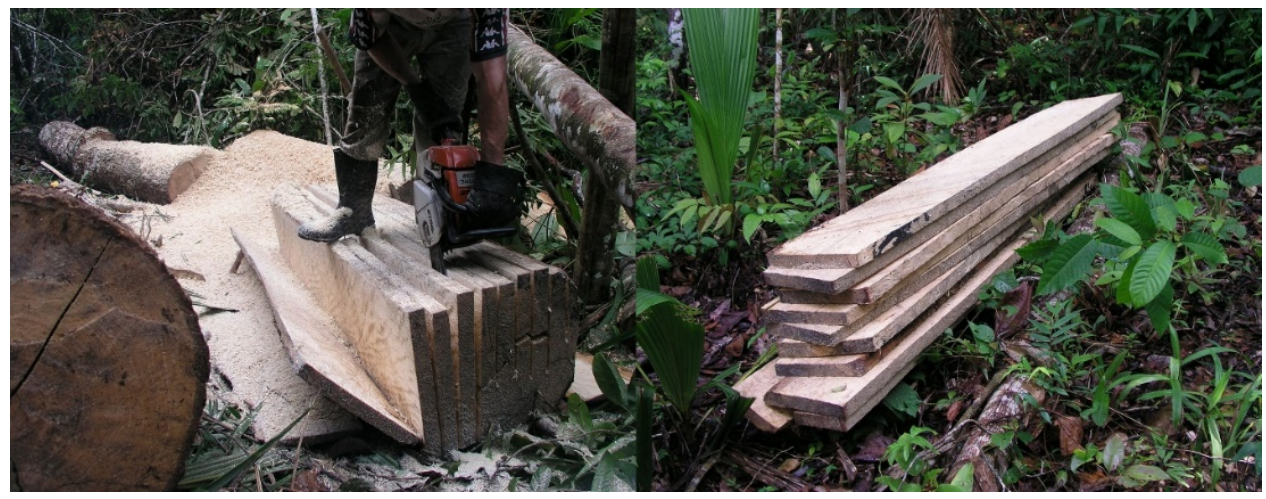

Figure 10: a) A valuable piece of timber being rendered into boards with a chainsaw (left). b) Resulting boards (right). 


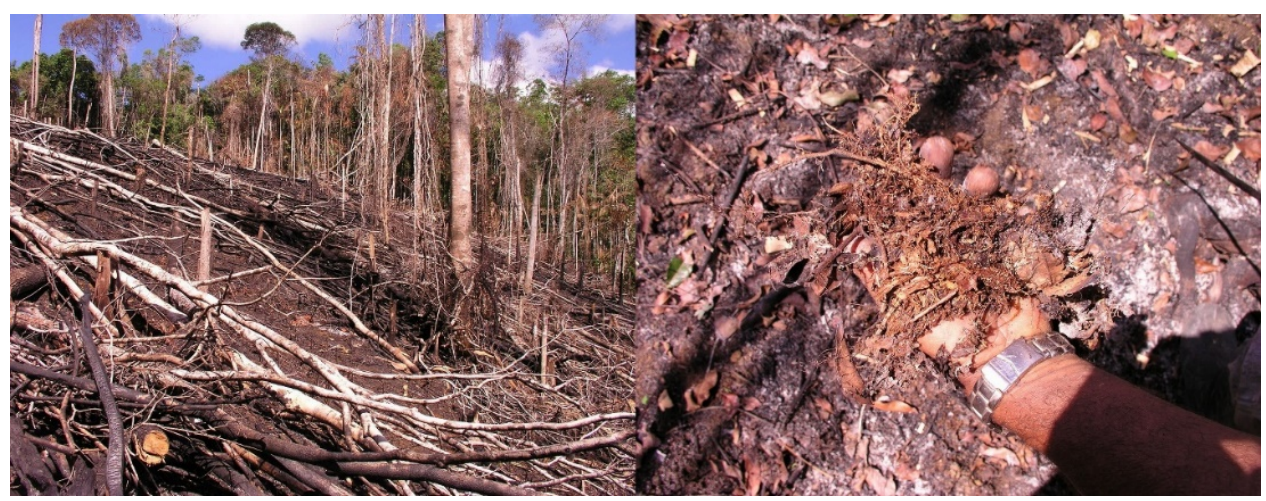

Figure 11: a) New farm plot after the first burn (same area as in Figures 9a and 9b) (left). b) Farmer demonstrating the quality of remaining organic material after the first burn (right).

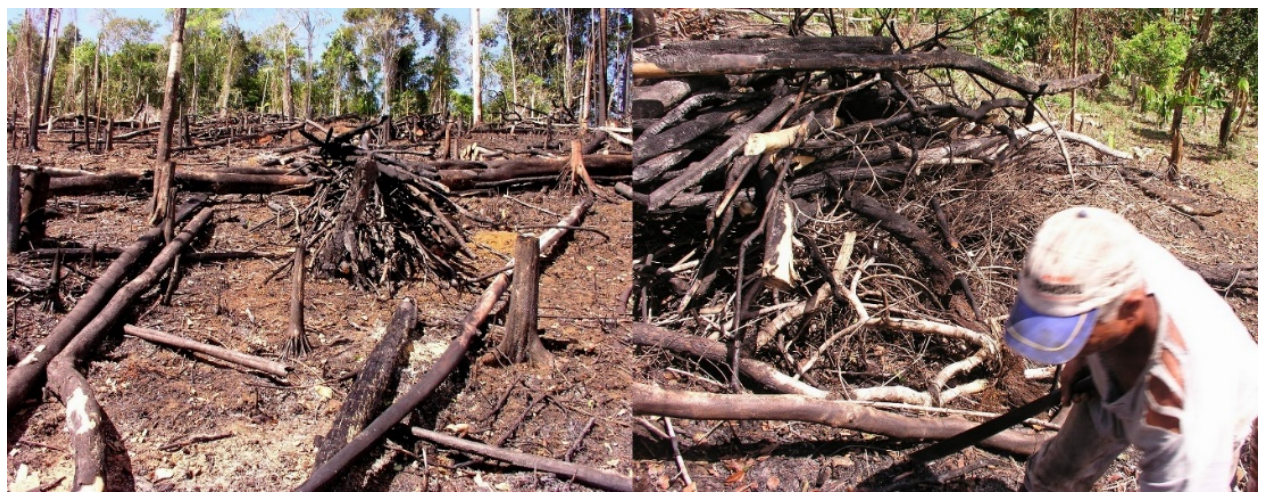

Figure 12: Small and medium-sized branches gathered into piles to be burned a second time.

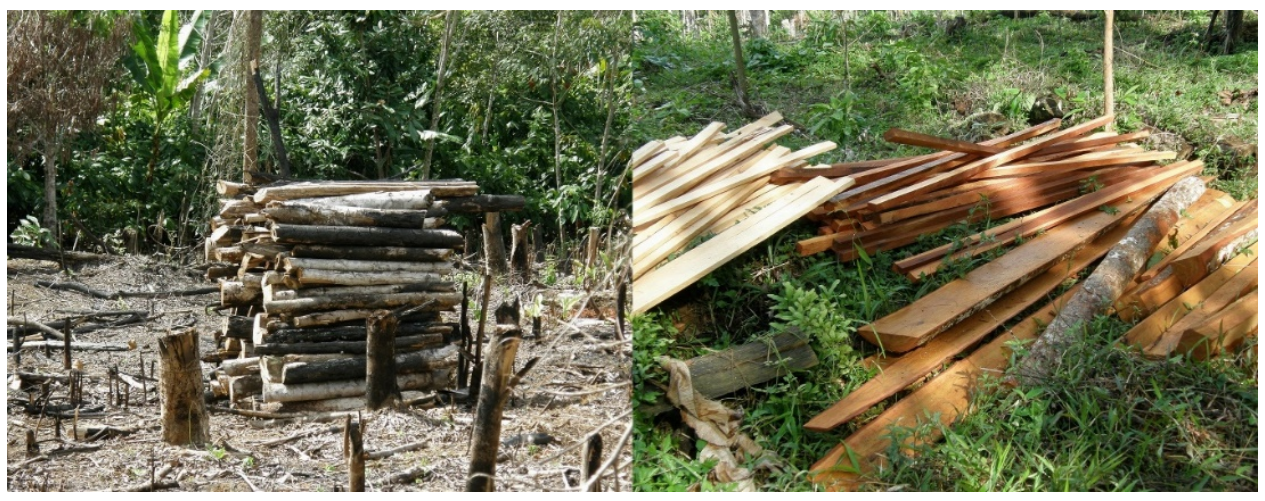

Figure 13: a) Tree branches left over from the burn to be used as firewood (left). b) Timber cut with a chainsaw into lumber of various sizes to build a small house (right).

Clearing and burning result in small quadrants of land, ranging between a half to a full hectare in size, which are ready for the initial phases of cultivation. Cultivation in this context aims at the establishment of perennial and diversified agroforestry systems, but often begins with the immediate propagation of either manioc or plantain bananas, both of which are harvested after about 12 to 18 months. These harvests quickly 
saturate household consumption needs, and most of the product is sold in local markets to generate cash flows. These initial plots receive a great deal of sunlight, and often include small gardens with beans, corn, and a wide range of vegetables aimed at household subsistence needs (Figure 14). From a conservation standpoint, these plots may appear to be opened at the expense of the rainforest; but to families at Nossa Senhora, these initial gardens were the inaugural moment of a long process of cultivation that imitates the successional patterns of natural forest growth.

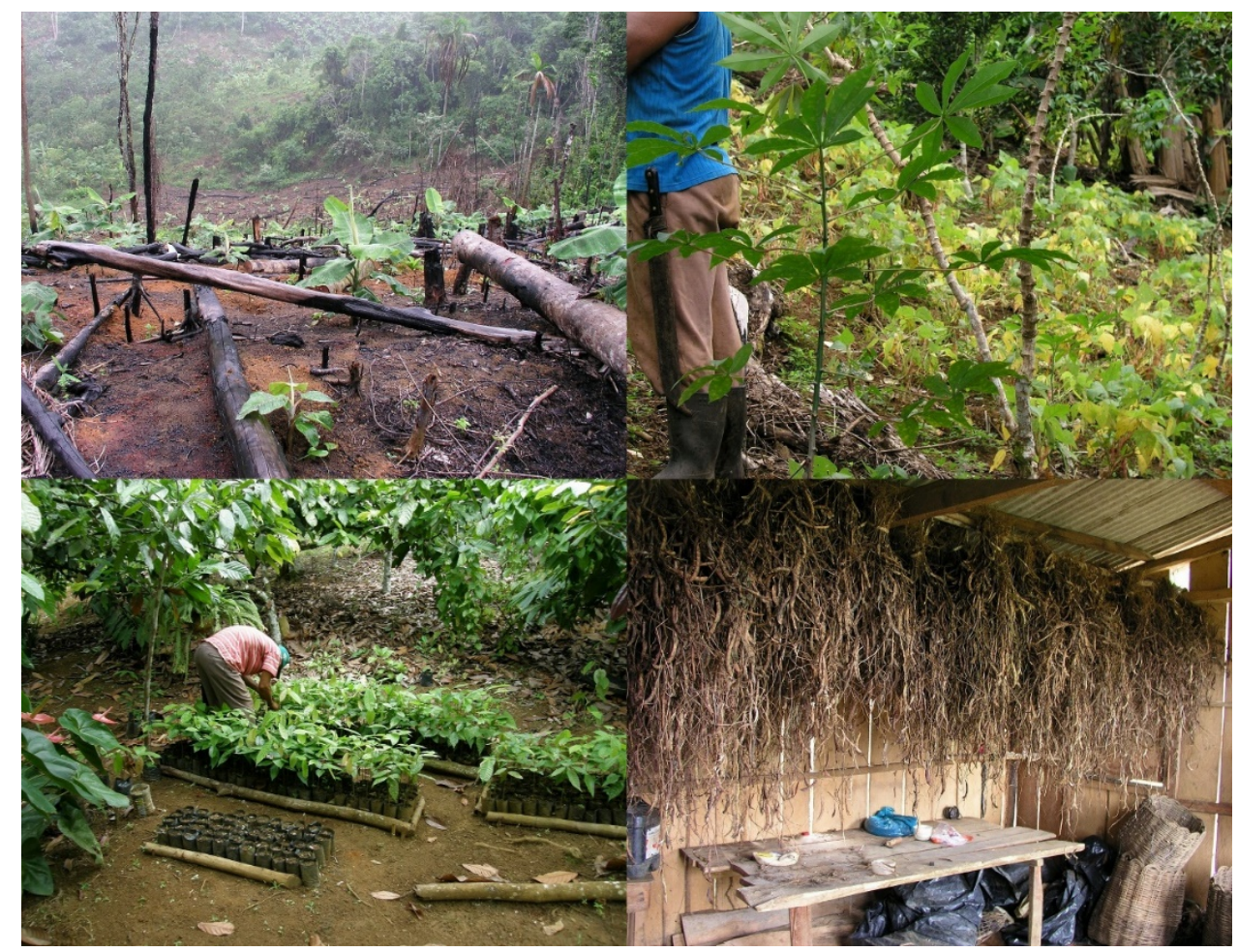

Figure 14: a) Young banana plants propagated in a recently opened field (top left). b) A few stray manioc plants in the foreground next to a plot of beans (top right). c) A small nursery of cacao seedlings in the shade of an established cacao grove (bottom left). d) Harvested beans drying in the shed (bottom right).

Squatters-turned-farmers quickly set out to procure cacao, rubber, and other tree seeds that they propagate and eventually plant in the midst of their gardens. These young tree saplings are protected from the sun under the shade of manioc or banana plants, as well as saplings of native secondary growth (capoeira) tree species that quickly sprout up in the newly burnt plots (Figure 15). Over the course of several years, what began as small gardens of temporary cultivars, initially oriented to both household subsistence and stimulating initial cash flows, eventually transform into agroforests that are increasingly oriented toward improving household cash flows through local market exchanges (Figure 16). The oldest plots where house structures are frequently built tend to include highly diverse mixes of fruit trees, vegetables, and herbs, as well as trees that produce cash crops; newer plots tend to more closely resemble the dual crop system of nearby plantations, with rubber trees occupying the canopy and cacao trees in the shade below. Plots at different stages of cultivation can be readily discerned on the physical landscape (Figure 17). 


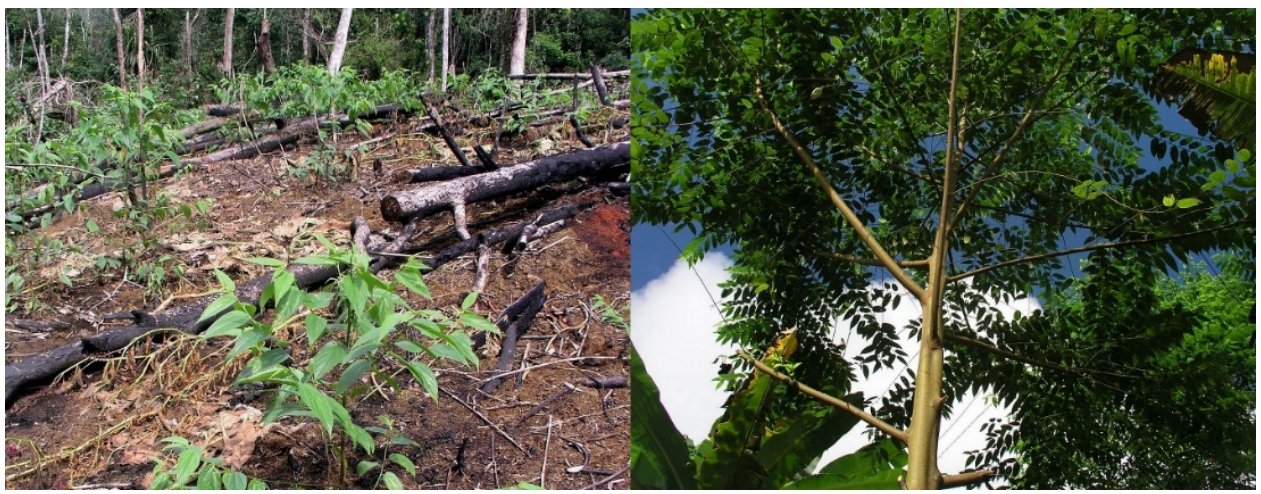

Figure 15: a) Saplings of a pioneer tree species called curindiba, very likely Trema micrantha, ${ }^{24}$ which are conserved in newly opened plots of land (left). b) These quickly growing, soil-improving heliophytic trees (Vázquez-Yanes 1998) provide shade to sciophytic trees that will be planted later (right). According to Posey (2002:174), these same trees are used by the Kayapó in their agricultural fields.

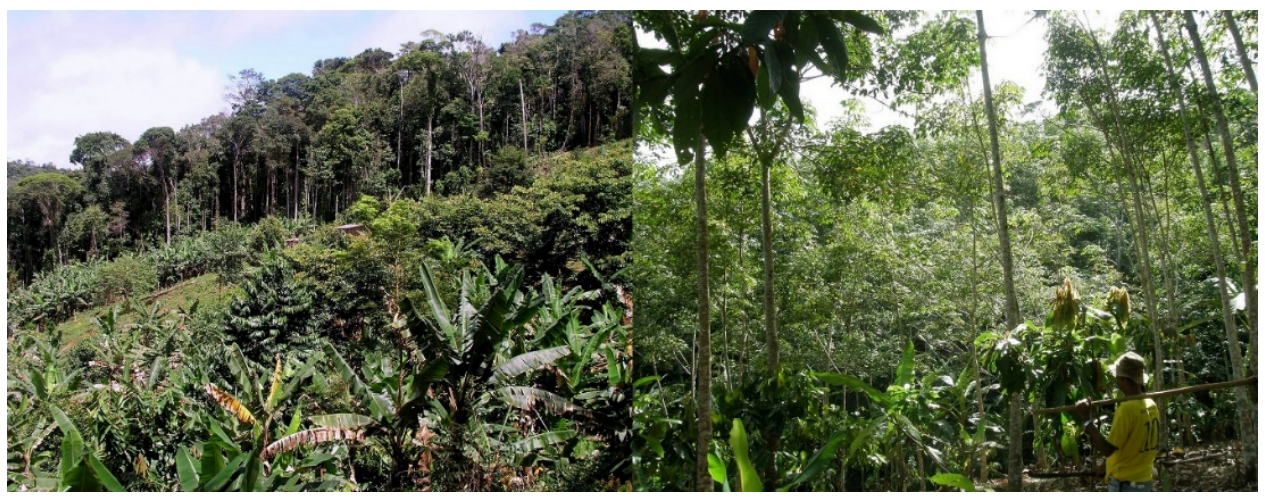

Figure 16: Agroforests at different stages of maturation.

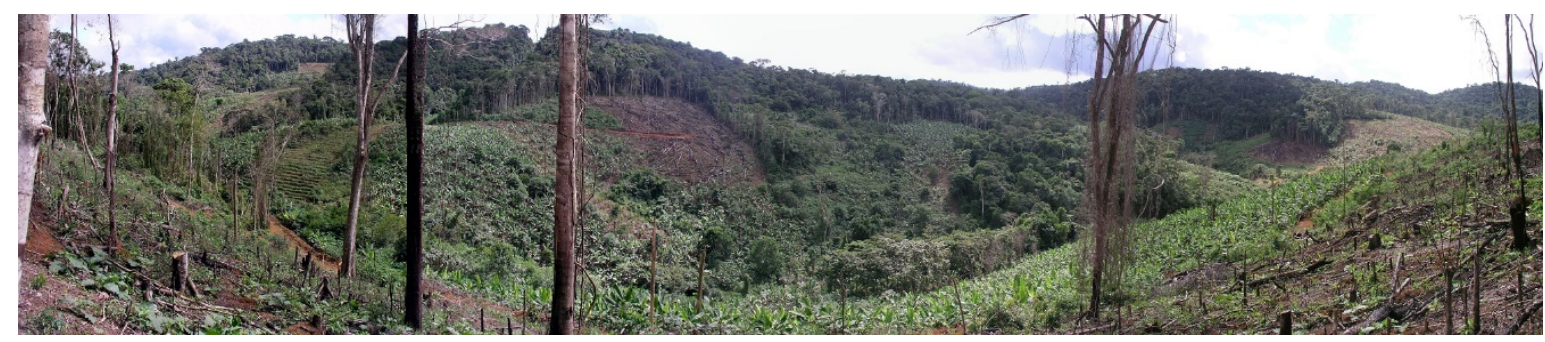

Figure 17: Hillside view of several squatter farmsteads with plots at different stages of cultivation.

\footnotetext{
${ }^{24}$ Michael A. Vincent (personal communication) helped me narrow down the genus and likely species on the basis of photographs of fruits and foliage.
} 
The processes of location, situation, and cultivation proceed through different kinds and degrees of social collaboration, and draw together various forms of human and non-human agency. Location intersubjectively locates the material boundaries and interpersonal limits within which labor processes may proceed, and aims at respecting the relationship between product and labor that are severed in plantation settings. Location also takes into account the temporal (future-oriented) anticipation of subsequent situation and cultivation, which often includes a small reserve of forest that may never be cleared and should not (normatively) be occupied by others.

The processes of situation and cultivation, especially in the first months of cultivation, occurred more collectively rather than individually, working in one family's plot on one day, in another family's plot another day, and so on. ${ }^{25}$ This was done in part for protection, as prior attempts to occupy the forests at Nossa Senhora in the 1980s had resulted in other groups' expulsion at the hands of gunmen hired by neighboring plantations. In subsequent months and years, cultivation processes normalized and proceeded according to each household's family labor. Different families and households, however, whether related by kinship or friendship, might still trade labor, barter for specific labor services, or simply help their neighbors. ${ }^{26}$ These processes, which at various turns are the result of social interaction and intersubjective coordination, result in the formation of private properties held by individual families.

These processes of property-making thus proceed through intricate social interactions that interweave the exercise of human agency together with other non-human powers. While some moments of this process may appears as destructive acts of appropriating or subduing "nature," the process of cultivation draws upon, recruits, and requires a whole set of biophysical and causal infrastructures that are not the direct products of human agency. This is as Ingold suggests: "the work of the farmer or herdsman does not make crops or livestock, but rather serves to set up certain conditions of development within which plants and animals take on their particular forms and behavioural dispositions" (Ingold 2000: 77). Thus, these private properties-far from being the product of individual human agency-are the result of complex social interactions that draw upon manifold relationships with non-human nature that figure into and also facilitate people's social activity. $^{27}$

\section{Conclusion: property democratization for degrowth?}

The descriptive purpose of this article has been to give a brief ethnographic account of the property claims that squatters in Bahia's cacao lands make to natural springs and agroforests. In so doing, I have sought to highlight intersections of different notions of property, access, and belonging, while reexamining some common ideas about "private" property. I suggested some ways that squatters' private claims both grew out of and helped foster affirming forms of sociality. In this sense, their private property claims to trees and springs are social property.

In previous work, I examined how actually existing forms of "collective" ownership in local MST communities had become enmeshed in patterns of asymmetrical accumulation and distributive injustice (DeVore 2015). This helped to make sense of why settlers in those communities articulated strong desires for non-collectively held land of their own. The point here was merely to suggest that property arrangements of

\footnotetext{
${ }^{25}$ See DeVore (2014:110-120) for a discussion of traditional patterns of work sharing in the region.

${ }^{26}$ As trees come into production and household finances improve, some families hire occasional day laborers for specific agricultural tasks, while others might contract with people to sharecrop their maturing rubber groves. This suggests a bourgeoning process of class differentiation. The recruitment of other people into these work processes also highlights a less obvious source of differentiation. As some family members grow old and less able-bodied, and younger family members migrate to urban areas to study or in search of wage labor, aging heads of household may find that there are fewer family members available to work the family farm. Perhaps more than class differentiation, the need to hire others to help with farm work indicates a double-dependency: their continued dependence upon farm income in old age, and their consequent dependence upon the able-bodied to keep the farm operating.

${ }^{27}$ Some people describe these causal interdependencies-especially with the trees that they cultivate-through idioms of kinship. People initially care for young saplings as "children" (filhos), which, later in the human life course, reappear as "mothers" (mães) that offer fruit and other sources of livelihood to increasingly aged and weary human bodies (DeVore 2014:469-472). A similar anthropomorphism is recognizable in Shel Silverstein's (1964) classic children's book, The giving tree.
} 
whatever sort may be social or anti-social in different ways. Building from that work, in this contribution I have sought to examine questions about "property" in relation to recent debates about "degrowth." My aim has been to encourage these timely conversations to take a detour around those Cold War antinomies that still hold some sway over political rhetoric and policy. While Foster (2011: 32) warns that the uncritical application of the "degrowth" concept to "wealthy countries of the center and the poor countries of the periphery" would amount to a "category mistake resulting from the crude imposition of an abstraction," the view I develop here is that it is a similar category error to think of property as reified "regimes" in opposition to one another. Perspectives available in property jurisprudence, economic anthropology, and political ecology help to make sense of how different forms of property intersect and interact.

None of the above has been concerned with specific prescriptions or measures to bring about degrowth. Let me conclude, then, by offering one idea for discussion. The radical ideal of a "propertyowning democracy"—as the outcome of a general right held by all, and not merely a formal opportunityhas been viewed unfavorably by partisans on the political Left and Right alike. ${ }^{28}$ The idea of a propertyowning democracy, to recall a phrase offered above, ${ }^{29}$ might be thought of as a situation in which all people had access to an independent and secure livelihood that did not depend upon the whims of an authoritative and controlling other. If the proliferation of landless and homeless movements throughout the world offers any indication, then access to such a "secure and independent livelihood" may well involve the democratization of land and home ownership.

What would be the consequences of such democratization? In Marx's (1976[1867]: 871-940) classic account of the emergence of capitalism, one of the key inaugural (indeed, ongoing) gestures was to expel the rural masses from the land in order to create a dependent and increasingly urban proletariat. In so doing, people had little choice but to participate as "sellers of themselves" (Marx 1976[1867]: 875) in capitalist processes of accumulation and growth. If that key inaugural gesture were reversed through the democratization of access to land and housing, as has occurred the small corner of Bahia described above, then people's "choice" to participate in such accumulative processes gains in substance-as does their ability to withdraw from them.

\section{References}

Agarwal, B. 1994. A field of one's own: gender and land rights in South Asia. Cambridge: Cambridge University Press.

Alexander, S. 2011. Property beyond growth: toward a politics of voluntary simplicity. Ph.D. dissertation. Melbourne: Law School, University of Melbourne.

Alexander, S. 2015. Basic and maximum income. In D'Alisa, G., F. Demaria, and G. Kallis (eds.) Degrowth: a vocabulary for a new era. New York: Routledge. Pp. 146-148.

Asara, V. and B. Muraca. 2015. Indignados (Occupy). In D'Alisa, G., F. Demaria, and G. Kallis (eds.) Degrowth: a vocabulary for a new era. New York: Routledge. Pp. 169-171.

Beitl, C.M. 2012. Shifting policies, access, and the tragedy of enclosures in Ecuadorian mangrove fisheries: towards a political ecology of the commons. Journal of Political Ecology 19:94-113.

Blackstone, W. 1979[1765-1769]. Commentaries on the laws of England. Volume 2. Chicago: University of Chicago Press.

Bollier, D. 2007. The growth of the commons paradigm. In Hess, C. and E. Ostrom (eds.) Understanding knowledge as a commons: from theory to practice. Cambridge, MA: MIT Press. Pp. 27-40.

Cohen, G.A. 1995. Self-ownership, freedom, and equality. Cambridge: Cambridge University Press.

Demaria, F., F. Schneider, F. Sekulove and J. Martinez-Alier. 2013. What is de-growth? From an activist slogan to a social movement. Environmental Values 22: 191-215.

Deriu, M. 2012. Democracies with a future: degrowth and the democratic tradition. Futures 44(6): 553-561.

\footnotetext{
${ }^{28}$ See Waldron (1988:423-445) for an extended discussion.

${ }^{29}$ See section 3 above where I draw upon Fraser's notion of participatory parity.
} 
de Soto, H. 2000. The mystery of capital: why capitalism triumphs in the West and fails everywhere else. New York: Basic Books.

DeVore, J. 2014. Cultivating hope: struggles for land, equality, and recognition in the cacao lands of southern Bahia, Brazil. Ph.D. dissertation. Ann Arbor, MI: University of Michigan.

DeVore, J. 2015. The Landless invading the landless: participation, coercion, and agrarian social movements in the cacao lands of southern Bahia, Brazil. The Journal of Peasant Studies 42(6): 1201-1223.

Escobar, A. 2008. Territories of difference: place, movements, life, redes. Durham: Duke University Press.

Farley, J. 2015. Steady state economics. In D'Alisa, G., F. Demaria, and G. Kallis (eds.) Degrowth: a vocabulary for a new era. New York: Routledge. Pp. 49-52.

Ferguson, J. 2015. Give a man a fish: reflections on the new politics of distribution. Durham: Duke University Press.

Foster, J.B. 2011. Capitalism and degrowth: an impossibility theorem. Monthly Review 62(8): 26-33.

Fotopoulos, T. 2007. Is degrowth compatible with a market society? International Journal of Inclusive Democracy 3(1).

Fraser, N. 1997. Beyond the master/subject model: reflections on Carole Pateman's The sexual contract. In

Fraser, N. Justice interruptus: critical reflections on the 'postsocialist' condition. New York: Routledge. Pp. 225-235.

Fraser, N. 2001. Social justice in the age of identity politics: redistribution, recognition, and participation. In

Fraser, N. and A. Honneth (eds.). Redistribution or recognition? A political-philosophical exchange. London: Verso. Pp. 7-109.

Fraser, N. and L. Gordon. 1994. A genealogy of dependency: tracing a keyword of the U.S. welfare state. Signs 19(2): 309-336.

Gluckman, M. 1965. The ideas in Barotse jurisprudence. New Haven: Yale University Press.

Goody, J. 1962. Death, property, and the ancestors: a study of the mortuary customs of the Lodagaa of West Africa. London: Tavistock Publications.

Grey, T.C. 1980. The disintegration of property. In Pennock, J.R. and J.W. Chapman (eds.) NOMOS XXII: property. New York: New York University Press. Pp. 69- 85.

Hann, C. 1996. Land tenure and citizenship in Tázlár. In Abrahams, R. (ed.) After socialism: land reform and social change in Eastern Europe. Providence: Berghahn Books. Pp. 23-49.

Hann, C. 2000. The tragedy of the privates? Postsocialist property relations in anthropological perspective. Working Paper No.2. Halle/Saale, Germany: Max Planck Institute for Social Anthropology.

Hardin, G. 1968. The tragedy of the commons. Science 162: 1243-1248.

Hecht, S. 2004. Invisible forests: the political ecology of forest resurgence in El Salvador. In Peet, R. and M.J. Watts (eds.) Liberation ecologies, second edition. Environment, development and social movements. London: Routledge. Pp. 64-103.

Helfrich, S. and D. Bollier. 2015. Commons. In D'Alisa, G., F. Demaria, and G. Kallis (eds.) Degrowth: $a$ vocabulary for a new era. New York: Routledge. Pp. 75-78.

Hess, C. and E. Ostrom. 2007. Introduction: an overview of the knowledge commons. In Hess, C. and E. Ostrom (eds.) Understanding knowledge as a commons: from theory to practice. Cambridge, MA: MIT Press. Pp. 3-26.

Hohfeld, W.N. 1923. Fundamental legal conceptions as applied in judicial reasoning, and other legal essays. New Haven: Yale University Press.

Honoré, A.M. 1961. Ownership. In Guest, A.G. (ed.) Oxford essays in jurisprudence. London: Oxford University Press. Pp. 107-147.

Ingold, T. 2000. Making things, growing plants, raising animals and bringing up children. In The perception of the environment: essays on livelihood, dwelling and skill. London: Routledge. Pp. 77-88. 
Locher, F. 2013. Les pâturages de la guerre froide: Garrett Hardin et la 'tragédie des communs.' Revue d'Histoire Moderne et Contemporaine 60-1:7-36.

Lund, C. 2001. African land tenure: questioning basic assumptions. In Benjaminsen, T.A. and C. Lund (eds.), Politics, property and production in the West African Sahel: approaches to natural resources management. Uppsala: Nordic Africa Institute. Pp. 144-162.

Kallis, G., F. Demaria and G. D'Alisa. 2015. Introduction: degrowth. In D'Alisa, G., F. Demaria, and G. Kallis (eds.) Degrowth: a vocabulary for a new era. New York: Routledge. Pp. 1-18.

Kingston-Mann, E. 2006. Claiming property: the Soviet-era private plots as 'women's turf.' In Siegelbaum, L.H. (ed.) Borders of socialism: private spheres of Soviet Russia. New York: Palgrave Macmillan. Pp. 25-45.

Macpherson, C.B. 1969. The political theory of possessive individualism: Hobbes to Locke. Oxford: Oxford University Press.

Malinowski, B. 1935. Coral gardens and their magic: a study of the methods of tilling the soil and of agricultural rites in the Trobriand Islands. Volume 1. Bloomington: Indiana University Press.

Marx, K. 1976[1867]. Capital: a critique of political economy. Volume 1. New York: Penguin.

Mayer, E. 2002. The articulated peasant: household economies in the Andes. Cambridge, MA: Westview Press.

McCandless, S.R. 2010. Stewarding the private commons: woodland tenure security, access, and conservation in Vermont. In McCandless, S.R Conserving the landscapes of Vermont: shifting terms of access and visibility. Ph.D. dissertation. Worcester, MA: Clark University. Pp. 60-105.

McCay, B.M. and J.M. Acheson, eds. 1987. The question of the commons: the culture and ecology of communal resources. Tucson: University of Arizona Press.

Meilasari-Sugiana, A. 2012. Collective action and ecological sensibility for sustainable mangrove governance in Indonesia: challenges and opportunities. Journal of Political Ecology 19:184-201.

Ostrom, E. 1990. Governing the commons: the evolution of institutions for collective action. Cambridge: Cambridge University Press.

Ostrom, E. 2000. Private and common property rights. In Bouckaert, B. and G. De Geest (eds.) Encyclopedia of law and economics, volume II. Civil law and economics. Cheltenham, UK: Edward Elgar. Pp. 332379.

Ostrom, E., M.A. Janssen and J.M. Anderies. 2007. Going beyond panaceas. Proceedings of the National Academy of Sciences 104(39): 15176-15178.

Pateman, C. 2002. Self-ownership and property in the person: democratization and a tale of two concepts. Journal of Political Philosophy 10(1): 20-53.

Posey, D.A. 2002. Kayapó ethnoecology and culture. London: Routledge.

Ribot, J.C. and N.L. Peluso. 2003. A theory of access. Rural Sociology 68(2): 153-181. Researchgate

Rose, C.M. 1999. Canons of property talk, or, Blackstone's anxiety. Faculty scholarship series, paper 1802. The Yale Law Journal 108: 601-632.

Scott, J.C. 1998. Seeing like a state: how certain schemes to improve the human condition have failed. New Haven: Yale University Press.

Scott, J.C. 2012. Two cheers for the petty bourgeoisie. In Two cheers for anarchism: six easy pieces on autonomy, dignity, and meaningful work and play. Princeton, NJ: Princeton University Press. Pp. 84100.

Silverstein, S. 1964. The giving tree. New York: Harper Collins.

van Griethuysen, P. 2012. Bona diagnosis, bona curatio: how property economics clarifies the degrowth debate. Ecological Economics 84: 262-269.

Vázquez-Yanes, C. 1998. Trema micrantha (L.) Blume (Ulmaceae): a promising neotropical tree for site amelioration of deforested land. Agroforestry Systems 40: 97-104.

Waldron, J. 1988. The right to private property. Oxford: Clarendon. 
Walters, B.B. 2012. Do property rights matter for conservation? Family land, forests and trees in Saint Lucia, West Indies. Human Ecology 40: 863-878.

Wittgenstein, L. 1953. Philosophical investigations. Oxford: Basil Blackwell.

Wolford, W. 2006. The difference ethnography can make: understanding social mobilization and development in the Brazilian Northeast. Qualitative Sociology 29: 335-352. 